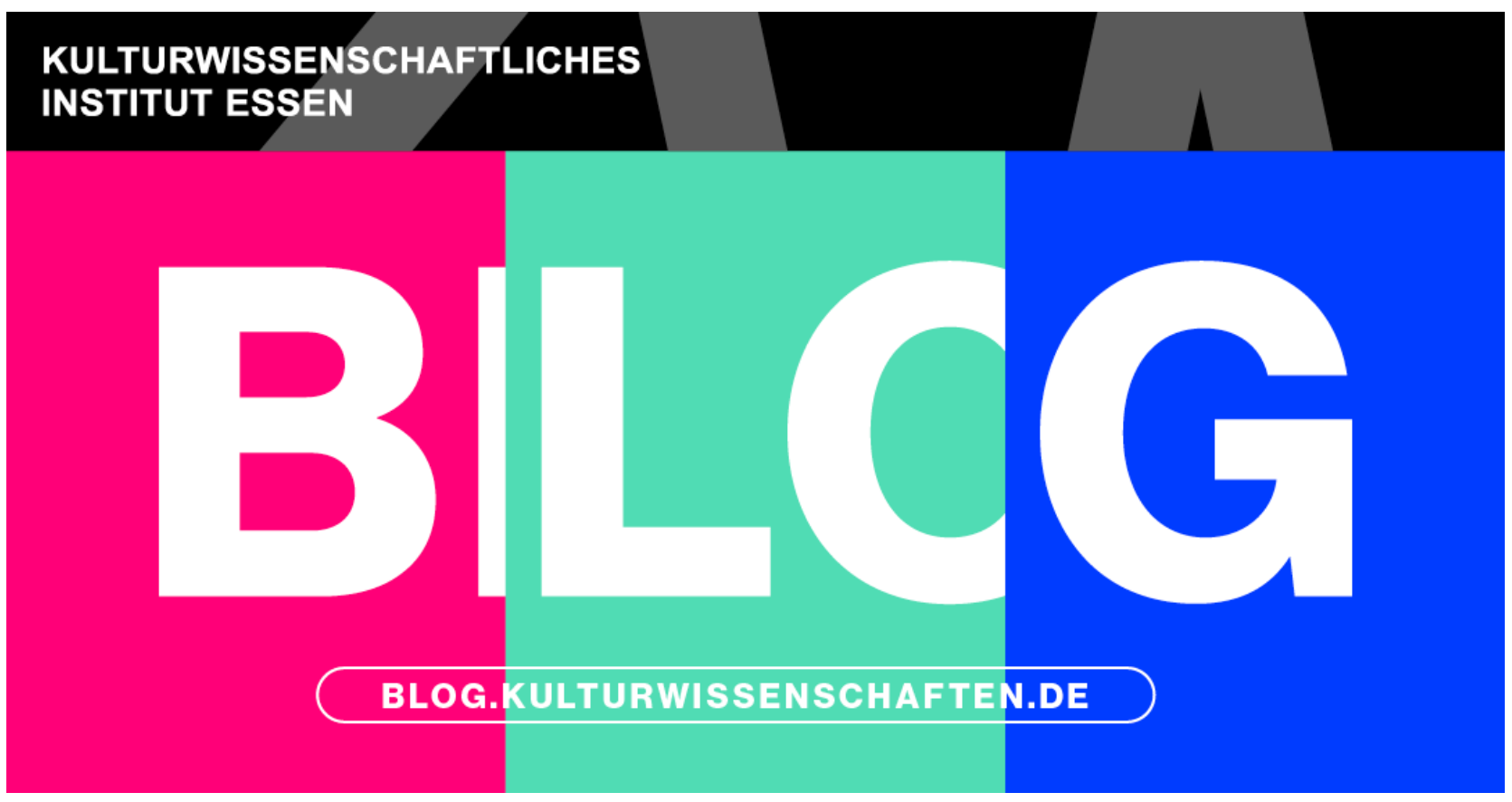

\title{
Making Academic Knowledge a Public Good
}

Von: Bécquer Seguín

Consider the following quote:

I am no stranger to censorship, since for years I was a censor myself... I experienced the regime's "most liberal" side while growing up. Nevertheless, I was trained in school to write and to read like a censor. My writing was censorious in its form and content in the same way the regime had been for years. I also read and thought censoriously, for I was constantly reminded of an authoritative and censorial entity poised to watch over my thinking process. Of course, growing up in Franco's Spain, I was not aware that I was a censor, [or] that censorship existed. ${ }^{1}$

Without looking at the citation, it might be difficult to guess where this quote comes from. A novel? A memoir? A personal essay? The passage might feasibly come from any one of these sources. However, the above passage in fact comes from the beginning of The Censorship Files by Alejandro Herrero-Olaizola. The Censorship Files is neither a novel, nor a memoir, nor a personal essay. Rather, it is a scholarly book. Published in 2007 by the State University of New York Press, the book examines how Latin American writers were censored in Francoist Spain during the 1960s and '70s. What we are meant to take from this introductory passage is that Herrero-Olaizola's personal narrative about censorship is indistinguishable from the scholarly analysis we hold in our hands. 
From my vantage point as a section editor for the magazine Public Books, HerreroOlaizola's book seems, in retrospect, like a missed opportunity. There is no question that the book itself is a significant scholarly achievement. It received universally positive reviews in the top journals of Iberian and Latin American literary studies. It secured the tenure and promotion of its author at the University of Michigan, Ann Arbor, one of the top research universities - and Spanish programs - in the world. However, the book had a chance to go well beyond the academy. A graduate course on non-academic writing, a dissertation committee that encouraged writing in a more popular vein, and a developmental editor to help reorient the book for a general audience would have been the only ingredients needed to make the book capable of reaching the wider public. And, even with these changes, the scholarly value of the book would not have suffered.

The Censorship Files isn't unique. Over the past several years, I have been surprised to find that there are many more similarly well-written scholarly books than the stereotype of bad academic writing might have us assume. Yet this common stereotype about bad academic writing is very powerful, and many have even speculated that the downfall of the humanities - in terms of economics, power, and prestige-is directly tied to how humanists write. One of these speculators is New Yorker staff writer and Harvard historian Jill Lepore.

In an interview for The Chronicle of Higher Education in 2018, Lepore issued the following judgment about the crisis of the humanities: "The academy is largely itself responsible for its own peril," she said.

The retreat of humanists from public life has had enormous consequences for the prestige of humanistic ways of knowing and understanding the world... Like any Ph.D. program, what you're being trained to do is employ a jargon that instantiates your authority in the abstruseness of your prose. You display what you know by writing in a way that other people can't understand. That's not how I understand writing. Writing is about sharing what you know with storybook clarity, even and especially if you're writing about something that's complicated or morally ambiguous. Also, I like to write about people who are characters, who have limbs and fingers and toes and loves and desires and agonies and triumphs and ages and hair colors. But that's not how historical writing is taught in a Ph.D. program. ${ }^{2}$

What Lepore says here is at once true yet outdated, insightful yet unsubstantiated. What seems true is that, at some point twenty to thirty years ago, many North American Ph.D. programs in the humanities trained students to use jargon unnecessarily. Yet the correlation between the way humanists write and the crisis in the humanities is specious at best and does not appear to be supported by empirical evidence. In fact, the empirical evidence points to certain widespread cultural perceptions as the culprit. As the data humanist Benjamin Schmidt writes, since 2011 North American students have been "fleeing humanities and related fields specifically because they think they have poor job prospects," 3 not because of jargon, the falling prestige of humanistic ways of knowing the world, or even the supposed retreat of humanists from public life. 
How we write in the humanities is, at best, epiphenomenal to the economic forces that have transformed North American universities over the past 40 years. However, that does not mean gainfully employed literary scholars should not spend more time reflecting on writing, rethinking how they write, and retraining themselves to write for a general audience. Might the end-goal for literary and cultural studies scholars be to develop a relationship with "the public"? Perhaps. Yet we should not buy into the myth that there was a past golden age of humanists in public life-a golden age to which we might return today.

In fact, this mythical golden age, if it ever existed, is going on right now. Today, many humanists write for general-audience publications. In my field of Iberian and Latin American literary studies, many scholars have stepped into the English-language public sphere: from scholar-translators such as Esther Allen and Heather Cleary and established scholars who have reinvented their careers such as Sebastiaan Faber and Ignacio Sánchez-Prado, to recently tenured scholars such as Craig_Epplin and Eric Calderwood. Dozens of other scholars in my field write for newspapers, magazines, and other public venues in Spanish, Portuguese, Catalan, Basque, and other languages. Still others are creative writers and journalists. This efflorescence of general-audience writing by North American scholars has happened, in large part, thanks to opportunity. The digital era has dealt a blow to the gatekeeping function of the handful of editors at elite magazines and literary periodicals thanks to the blossoming of new publications of literary and cultural commentary. There is Public Books, the magazine I work for, along with many others: Guernica, Lit Hub, Electric Literature, Full Stop, Brittle Paper, $\underline{\text { Hyperallergic, }}$ and The Millions. These are just a sampling of the many online magazines that regularly publish writing by seasoned scholars. Even at less literary-focused venues, from start-up web sites like The Ringer to established publications like New York magazine, there is a clear and growing demand for cultural commentary informed by scholarship. Alongside the demand for book reviews and essays, there is also a demand for other forms of writing that require significant knowledge about the arts, from podcasting to multimedia storytelling.

If general-audience writing is so widespread today, then the term "public humanities" has likely outlived its usefulness. In fact, the term may even be counterproductive to making academic knowledge a public good. It preserves rather than dissolves the enduring opposition between "scholarly" and "public" work. It doubles down on stereotypes that are regularly, if sometimes inadvertently, upheld by academic colleagues, hiring committees, and the university ecosystem at large. As the scholar and critic $\underline{\mathrm{Hua} H \mathrm{Hu}}$ has summarized it:

The problem in our profession is that writing well... is often disparaged as pandering and surrendering to a populace that merely wants to be entertained. Clarity and accessibility are not pandering. Editing, thinking about structure and length, and revisiting our reliance on jargon and shorthand: these are not forms of surrender. Understanding one's audience and critiquing 'neoliberalism' without using the word are not forms of retrenchment. Understanding how journalism and the media work does not tarnish our profession. On the other hand, posting something on Facebook is not journalism. ${ }^{4}$ 
Instead of upholding distinctions between scholarly and public writing, we would be better served rethinking what counts as research in fields across the humanities. Some scholarly associations are already trying to level the playing field between scholarly and public work. In a document titled "Open Proposal on Academic Practices," dozens of tenured scholars of contemporary Spanish literature and culture committed to counting "publications in non-academic platforms" in their evaluations for tenure and promotion, regardless of the institution's own position on the relevance of these publications. This momentous decision was taken collectively by an entire scholarly field. More scholarly fields in the humanities should follow their example. The move is an attempt to wrest power back from those who would like to keep academic knowledge a private endeavor. Our scholarly community, like the one envisioned by these tenured professors of Spanish literature and culture, should be one in which specialized conversations take place at the pitch of a general audience.

Back in 2014, New York Times columnist Nicholas Kristof claimed that "Ph.D. programs fostered a culture that glorifies arcane unintelligibility." 5 At the time, I was a graduate student in Romance Studies at Cornell University, a humanities department that had historically prided itself on proselytizing the arcane unintelligibility of deconstructive literary criticism. ${ }^{6}$ If anyone was in a prime position to agree with Kristof, I was. Yet I didn't agree with him-and I still don't. The problem with writing in the humanities today isn't that professors and graduate programs value jargon. It's that they encourage inattention to writing. If we want to make academic knowledge a public good, rather than keep it a private possession, paying more attention to how we write can help us get there.

\section{References}

1. Alejandro Herrero-Olaizola, The Censorship Files: Latin American Writers and Franco's Spain (Albany: State University of New York Press, 2007), xi.

2. Jill Lepore interviewed by Evan Goldstein, "'The Academy Is Largely Itself Responsible for Its Own Peril,"' The Chronicle of Higher Education, 13 November 2018.

3. Benjamin Schmidt, "The Humanities Are in Crisis," The Atlantic, 23 August 2018.

4. Hua Hsu, "The Context of Infinite Contexts," PMLA 130.2 (2015): 465. https://doi.org/10.1632/pmla.2015.130.2.461.

5. Nicholas Kristof, "Professors, We Need You!" The New York Times, 15 February 2014.

6. I have briefly written about how I began writing journalism during graduate school. See Bécquer Seguín, "Why Write for the Public," Post45, 30 July 2019.

SUGGESTED CITATION: Seguín, Bécquer: Making Academic Knowledge a Public Good, in: KWI-BLOG, [https://blog.kulturwissenschaften.de/making-academicknowledge-a-public-good/], 11.10.2021

DOI: https://doi.org/10.37189/kwi-blog/20211011-0830 
DuEPublico

Duisburg-Essen Publications online
DEUISB BN R G

offen im Denken Ub $\mid \begin{aligned} & \text { universitäts } \\ & \text { bibliothek }\end{aligned}$

This text is made available via DuEPublico, the institutional repository of the University of Duisburg-Essen. This version may eventually differ from another version distributed by a commercial publisher.

DOI: $\quad$ 10.37189/kwi-blog/20211011-0830

URN: urn:nbn:de:hbz:464-20211011-111739-0

All rights reserved. 